\title{
Correcting Feedback on Essay Composition: EFL Students' Preferences between Traditional and e- Feedback
}

\author{
Ariyanti \\ Widya Gama Mahakam University Samarinda, Indonesia \\ e-mail: ariyanti.muflihin@gmail.com \\ Dedi Rahman Nur \\ Widya Gama Mahakam University Samarinda, Indonesia \\ e-mail:d.blues84@gmail.com
}

\begin{abstract}
Writing is one of skills in English language proficiency which is considered as a complex and important element to passive communication. In addition, an ability to write good composition has become one of requirements to successful life in many major aspects. Specifically to particular unit in learning writing in EFL classroom, feedback is the key for students to get their essay quality improved better. Therefore, this study is aimed to investigate feedback given by writing lecturer whether in traditional and e-feedback, as well as digging students' preference towards those methods. Classroom observation and students' open-ended questionnaires were used as major instruments, while semi-structured interview to writing lecturer was also used as supporting data. The result showed that most of the students prefer to be given the e-feedback to assess their essay instead of the traditional one. This study also reveals high expectation to the use of vary electronic media from the students, therefore future implication is clearly derived to the creativity of writing lecturer so that the students will be more motivated and surely improved in terms of structural and content aspects of writing.
\end{abstract}

Keywords: Correcting feedback, essay composition, EFL students' preference, traditional methods, e-feedback 


\section{INTRODUCTION}

Writing is one of the major productive skills which very important nowadays. Since a long time ago until the present time, people have used so many tools to communicate through writing such as letters, emails, blogs, etc. In this case, Ariyanti (2016a) stresses that the use of passive English is also as important as active English to deliver messages. In addition, in terms of essay writing, it is urgent for students to highlight that writing is not only a matter of describing a theme without any goal which a writer would like to gain (Ariyanti, 2016a). For instance, an ability to write a good essay is one of the requirements to determine the successfulness of students who are eager to apply for certain scholarship abroad. Additionally, in the future when the students are ready to work, arranging eligible business letters also becomes an urgent matter for them.

Considering the importance of writing as a mean of transferring messages in written form as well as one of the major skills in English language acquisition which EFL students should master, there have been many researchers who had conducted a study regarding with writing. For instance, investigating a matter of the causes that influence the students' writing performance, how to improve the ability of students' writing, explore how writing lecturers establish their writing classes with certain method, what is students' perception and preferences towards the methods used by the lecturer.

The first previous study came from Huwari \& Al-Khasawneh (2013), where in their research, they found several major problems faced by students such as grammatical terms, lack of comprehension towards how to produce a good writing, and students' educational background. Rezaei \& Jafari (2014) who investigated about factors that influence the students' writing production, specifically about the cause, level, and types of anxiety appeared in learning writing. They detected a high level of cognitive anxiety where the students are stress with high expectation set by the lecturer and they also afraid of negative feedback that they believe that they have lack of ability in a linguistic matter so that they perform low confident.

Referring to the study from Rezaei \& Jafari (2014), feedback from the lecturer played an important role in improving the students' writing ability. That study is also supported by a research from Ariyanti (2017), where she found that in High Anxiety Level was indicated from the apprehension of obtaining negative comment from the lecturer. Furthermore, another study related to the importance of feedback came from Ahmadi, Maftoon, \& Mehrdad (2012). Specifically, they noted that students who were treated by using corrective feedback whether in direct or indirect feedback performed better writing than those who did not.

In support with Rezaei \& Jafari (2014), Ariyanti (2017), and Ahmadi et al. (2012), Sanu (2016) also had a research on feedback used by a lecturer towards students' business letters writing where he explored the students' preferences towards the feedback given by the lecturer. In his research, he found that lecturerstudents conferencing is at the top of student's preference to correct their writing because they got appreciation both from the lecturer and other friends as well as knowing their weaknesses in writing the business letters as a class. 
Relying on above theories and studies from several researchers, this study is aimed to explore the perception as well as the preference of EFL students from Widya Gama Mahakam University, Samarinda, Indonesia, towards their lecturer's teaching writing method. Unlike with Sanu (2016), this study focuses more on traditional and e-feedback used by the lecturer to have comments on the students' essay, where previously the researchers ensured to the lecturer of what kind of methods she usually used in teaching English essay writing. The further expectation of this research is the researchers can explore what kind of e-learning media she applied in the classroom.

\section{LITERATURE REVIEW}

\subsection{Expected and Unexpected Feedback}

There are still so many scholars and researchers argue on how to give correcting feedback to the students' essay. Farid \& Samad (2012) point out that the most problem occurs is whether the feedback given is suitable and acceptable for the students, even though many research has been conducted to investigate which method is effective to correct the students' essay composition.

Particularly, above issue is raised from the students' perception towards the feedback given by the lecturer. As Price et al. (2010) observe that students do not really respect to the correcting feedback given because they perceive confusion towards the correction. Ambiguous notes on their essay result in negative attitudes towards their essay drafting and revising process. In addition, it makes them leave aside the importance of feedback from their lecturer as well as having less motivation to improve the quality of their essay writing production. Price et al. (2010) also add that traditional handwritten feedback sometimes is very difficult to understand. Therefore, these kinds of feedback drive them to think that the lecturer's corrections do not mean too much for their writing.

However, the students must pay attention to the feedback given by the lecturer even though above-unexpected realities often come in the real situation of essay writing class. In this case, Ariyanti (2016b) says that both the lecturer and students should cooperate in order to build a meaningful teaching and learning process of writing. Particularly, the students should ask for the lecturer's notes which make them confuse and the lecturer should explain what he wanted the students to do the revision. After all, the students will feel pleasure to revise their essay draft. In addition, Chang et al. (2012) explain that direct communication with face to face meeting between the lecturer and students will be very helpful for the students to get clarity as well as detail explanation to every aspect that the students need to figure out. This choice of having an interactive model of feedback is considered to be very beneficial both for the lecturer and students where the lecturer will be very glad for the students' improvement on their essay production, while the students will feel happy for a clear explanation from the lecturer towards the content of their essay.

\subsection{The Concept of Correcting Feedback}

Referring to the importance of giving feedback to the students, the researchers feel delightful to explain the types of correcting feedback which is normally used by 
lecturers towards their students' essay composition performance. There are two types correcting feedback which are proposed by Lipnevich \& Smith (2008), they are intentional and unintentional feedback. In terms of intentional feedback, it refers to correction given by lecturer to assess students' essay production to check for the quality and correctness of the essay content. In addition to the second type of corrective feedback, unintentional one is the way to correct the student's essay in a natural setting in the class. It means that the lecturer makes a correction in accidental condition when he has physical interaction to the students.

Moreover, in terms of kind of information given by the lecturer on the students' essay also can be categorized into two types according to Linn \& Miller (2005), they are descriptive and evaluative feedback. Descriptive feedback refers to lecturer's revision which is contained the description on how the students perform as well as providing the students with detail information with the intention to help the students with difficulties they are facing in order to increase the students' ability in composing the essay. Meanwhile, evaluative feedback is more concerned about judgment and correctness on the students' essay performance.

Particularly, those kinds of correcting feedback are commonly used by lecturers in two methods of teaching, traditional and e-feedback. Traditional method means that the lecturer does paper based revision where he writes the corrections and comments directly to the students' essay. On the other side, if the lecturer gives e-feedback, the students' essay will be corrected by using modern technological appliances. As the theory of e-learning in general which is suggested by Rajaram (2009) where it is defined as the use of digital media in the teaching and learning process in the classroom such as computer and cellphone which can be connected to the internet. In addition, Rajaram points out eight types of tools for e-learning with a brief explanation as follow:

- Emails: The method is like sending letters via electronic devices. The students can write messages on the email or attach the writing assignment.

- Mailing Lists: A group of communication through a listserv/ mail server program where many people with different email addresses are maintained. In this case, people who use the mailing list can share information and have comments about the certain area such as "essay writing", "writing for novice", "advance writing", etc.

- Newsgroups: A discussion forum to share ideas where people should register at a given link to join the group so that they can post and comments on particular information. Just like mailing lists, newsgroups are usually designed for people with different interest such as "professional researchers", "published journal writers", "academic writers", etc.

- Bulletin Boards: It is usually provided by many websites where by using this tool, people can work together online to accomplish an essay.

- Instant Messaging: In instant messaging, people can have a list of friends to share knowledge when the person we want to have a chat with is also online together at the same time with us. 
- Chat or Conferencing: It is a communication method where people engage together in the online platform at a decided time. They also can share their thoughts on a chat box.

- Internet Telephony: It is a discussion method that enables people to have voice communication via the internet. In order to have a clear sound of two people communicating each other though the internet, they need to consider fast internet connection, microphone, and big RAM capacities.

- Weblogs: Blogs are kind of personal website where people can post anything about their thought and creation.

From all kinds of correcting feedback mentioned above, Sambell (2011) says that below pedagogic principles in Assessment for Learning (AfL) are considered very important in writing:

- Rich in formal feedback: Comments from lecturers.

- Rich in informal feedback: Feedback through dialogues between a lecturer and students as well as students' pair reviewing and discussion.

- Emphasizes authentic assessment: Writing task given should be very "important" and has valuable significances for learning.

- Provides chances for low-stakes assessment practice: The lecturer should believe that writing successfulness is achieved from the process of drafting which includes many practices, writing skills training, and critical thinking promotion so that the lecturer cannot directly give a mark on the students' essay before realizing above facts.

- Build students' independence and autonomy: By providing sustainable feedback, the lecturer gives opportunities to the students to keep an eye on their learning progress.

- Balance summative and formative assessment: Not only giving a final mark on the students' essay but the lecturer also pay high attention to the process of drafting.

\section{RESEARCH METHOD}

\subsection{Research Design}

The history of qualitative research is on the use of the hermeneutic approach to investigate, explore, and interpret deeply related to daily life activities happened in the setting of natural phenomenon in terms of individual or group (Leavy, 2014). This study is a qualitative study where the researchers tend to display the result in the form of descriptive explanation. Specifically, the researchers describe the corrective feedback both in traditional and e-feedback used by the lecturer as well as the students' perception and preference towards those methods.

\subsection{Research Subject}

The research subject of this research is seven students from the fourth semester at Widya Gama Mahakam University Samarinda, Indonesia. Particularly, these seven students come from an exclusive class where the total number of the students are not as many as the regular class. This consideration is taken by the researchers because 
they believe that they will gain accurate and expected data related to the research topic.

\subsection{Research Instruments}

Observation. This instrument was used to capture the writing activities in the classroom. Open-ended questionnaire: The researchers distributed an open-ended questionnaire to the students in order to obtain their perception and preference towards traditional and e-feedback used by the lecturer to improve their writing quality. Semi-structured interview: the Semi-structured interview was conducted to the lecturer in order to investigate her perception towards her methods when teaching writing in the classroom.

\subsection{Data Collecting Procedures}

In order to obtain an expected result, the researchers formulated below steps in collecting the data. The researcher asked permission to Gatekeeper; a person who has an official role at the place where the researchers conduct their study (Creswell, 2012). In his case, the researchers asked for permission from the lecturer to observe her writing class. Specifically, the researchers acted as a passive observer where they did not interplay the process of teaching and learning in the classroom. The researchers distributed an open-ended questionnaire to each student. To avoid misunderstanding from the students, one of the researchers explained about the questionnaire items. The researchers conducted a semi-structured interview as additional data to support major data obtained from the observation and open-ended questionnaire.

\subsection{Data Analysis Techniques}

Analyzing the data is a major aspect of collecting them in a specific amount of time. Particularly, the researchers used Flow Model of Qualitative Data Analysis proposed by Miles, Huberman, \& Saldana (2014) which explained briefly as follows: 1) Data Reduction: In this step, the researchers reduce unexpected data from the research instruments which have no relation to the research objectives, 2) Data Display: After sorting of process of reducing the data, the researchers display the data in the result part of the research, and 3) Data Verification: In this step, the researchers verify the result by triangulation and member checking (Creswell, 2014).

\section{FINDINGS AND DISCUSSION}

\subsection{Overview of Methods Used by the Writing Lecturer}

In this research, the researcher observes two types of methods used by the lecturer in giving feedback to the students' essay writing, they are traditional and efeedback. In traditional feedback, the students' essay is corrected manually by handwritten correction. Meanwhile, e-feedback is a method which is used by the lecturer by using email as a tool for sending the essay to the students as well as the feedback by the lecturer. Additionally, the lecturer conducts essay consultation every time he gives feedback to the students. The students have face to face interaction to ask for clarification related to the lecturer's notes individually. 
In achieving the score for the essays, the students have to follow the drafting processes which are explained briefly as follows:

Draft 1 : Explanation of an essay concept - discussion - outlining - draft 1 (the students can take the draft 1 home whenever they have not finished) draft 1 is collected.

Draft 2 : Feedback of draft 1 is given - essay feedback consultation - draft 2 is done (the students can take the draft 2 home whenever they have not finished) - draft 2 is collected.

Draft 3 : Feedback of draft 2 is given - essay feedback consultation - draft 3 is done (the students can take the draft 3 home whenever they have not finished) - draft 3 is collected as a final draft.

\subsection{Lecturer's Perception towards the Feedback Methods}

The perception of the lecturer is gained from the semi-structured interview done to the lecturer by the time the lecturer had free time to talk to the researchers about the methods used by him in assessing the students' essays. Firstly, the lecturer said that to give feedback to the students' writing is a must for him as an educator and he will always count on corrective feedback to assess the students' essay production. It intends to provide the students with full understanding related to his correction. He also added that by giving feedback to the students' essay, he believes that it will influence the students' psychology where they will feel glad and happy because the lecturer reads their essays thoroughly.

In addition, a matter of fairness is also stressed by the lecturer because in assessing the students' essay, it is not fair if the writing task is acquired just to fulfill the successfulness criteria to pass the course. It is important to appreciate and pay attention more to the process on essay writing through drafting processes.

\subsection{Students' Perception and Preference towards Methods Used by the Lecturer}

TABLE I. STUDENTS' PERCEPTION

\begin{tabular}{|c|c|c|}
\hline \multirow{2}{*}{ Subjects } & \multicolumn{2}{|c|}{ Corrective Feedback Methods } \\
\hline & Traditional feedback & e-feedback \\
\hline Student 1 & $\begin{array}{l}\text { - Paper and ink waste } \\
\text { - Time and power consuming }\end{array}$ & $\begin{array}{l}\text { - Save paper and ink } \\
\text { - Effective } \\
\text { - Easy to send the draft anywhere }\end{array}$ \\
\hline Student 2 & $\begin{array}{l}\text { - Good, because of clear } \\
\text { explanation from the lecturer }\end{array}$ & $\begin{array}{l}\text { - Good, because of clear explanation } \\
\text { from the lecturer }\end{array}$ \\
\hline Student 3 & $\begin{array}{l}\text { - When revising the writing } \\
\text { draft, the students should write } \\
\text { the essay all over again }\end{array}$ & $\begin{array}{l}\text { - Just need to copy and paste the file of } \\
\text { the draft, then edit the file for the next } \\
\text { draft } \\
\text { - The use of laptop and internet reflect } \\
\text { technology advances }\end{array}$ \\
\hline Student 4 & $\begin{array}{l}\text { - Sometimes there are some } \\
\text { notes from the lecture which } \\
\text { cannot be understood well }\end{array}$ & $\begin{array}{l}\text { - The revision is easy to understand } \\
\text { because the correction is in typed form }\end{array}$ \\
\hline Student 5 & - No need to be afraid of bad & - Bad internet connection \\
\hline
\end{tabular}




\begin{tabular}{|l|l|l|}
\hline \multirow{2}{*}{ Subjects } & \multicolumn{2}{|c|}{ Corrective Feedback Methods } \\
\cline { 2 - 3 } & \multicolumn{1}{|c|}{ Traditional feedback } & \multicolumn{1}{c|}{-feedback } \\
\hline Student 6 & $\begin{array}{l}\text { • Good to train the students to } \\
\text { have neat handwriting }\end{array}$ & $\begin{array}{l}\text { ・ Sophisticated in terms of bringing the } \\
\text { laptop }\end{array}$ \\
\hline Student 7 & $\bullet$ Time consuming & $\bullet$ Easier to edit the draft \\
\hline
\end{tabular}

\section{FIGURE 1. STUDENTS' PREFERENCE}

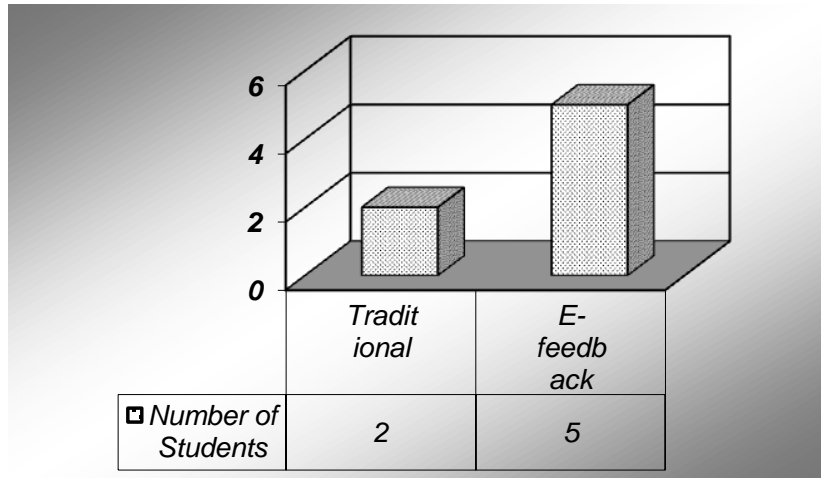

\subsection{General Comments and Suggestions from the Students towards the Feedback Given}

For the students, feedback is very important to improve their ability in writing. They think that it is an urgent matter since the lecturer always read their essays in detail and give corrections such as grammatical rules, diction, how to connect ideas between paragraphs, etc. The most part that the students like the best are when the lecturer pleases them to come forward one by one to discuss the feedback given by the lecturer. In this case, they are free to ask any confusion they need to be clarified.

Without leaving aside the benefits of corrective feedback, the students note that materials given should be more varied and not monotonous. Moreover, the use of more creative technology is also suggested by the students since the electronic media used by the lecturer is emails to send the writing assignment as well as the feedback. In this case, the students add that the use of blog can help them in improving their writing ability while still promoting technology in advance.

To discuss further, most of the students prefer to experience e-feedback in learning writing. It is no doubt that e-learning can give many benefits for the process of teaching and learning writing. The use of e-learning is low cost, potentially give better learning result, and the students can match to their schedule so that they can access the learning materials and do assignments every time and anywhere (Efrontlearning, 2014). Moreover, to this modern era where technology develops faster, today's process of teaching and learning have already used electronic media and follow the update trends. It is because e-learning can affect education's life in a positive way, such as the use of blogs as one of the representative media to post the students' writing by themselves where their classmates and lecturer can possibly give feedback by writing directly to the blog (Amir, Ismail, \& Hussin, 2011). 
However, the quality of writing teachers needs to be improved, therefore they can use vary media of e-learning to enhance the students writing ability as well as to attract the students' attention in order to high up their spirit in writing better essay writing. In this case, Ghirardini (2011) suggested that teachers can do below procedures in preparing e-learning materials:

1. Designing e-learning course: The teacher should examine needs, targets, and topics of learning. In addition, the teacher also needs to rely on learning objectives and how to deliver the content of materials.

2. Creating interactive content: Provide students with the clear guidance on how to use certain e-learning media, particularly from how to use it and what learning strategies that the students must apply. The teacher also needs to make the content interesting for the students.

3. Managing and evaluating learning strategies: To do this step, the teacher should understand how to manage the e-learning platform and how to evaluate the students' works through online media basis.

Since e-learning including e-feedback in teaching and learning writing becomes important, this research comes to the fact that writing lecturer should face and cope with the students' expectation of experiencing more vary electronic media in giving e-feedback to their writing. It means that more creativity is needed in teaching the students to meet their necessity as well as to increase their motivation to have a well-written essay in terms of content and structural aspects.

\section{CONCLUSION}

The above result and further discussion, in fact, confirm to nowadays educational necessity of e-learning. Specifically, most of the students choose efeedback as the method of assessing and giving comment on their essay. Not only the students, the writing lecturer also assumes that feedback is the heart of gaining a better quality of students' writing, and electronic media makes it perfect to represent technology development. However, even though most of the students prefer the efeedback to be used in the process of teaching and learning of essay writing, some of them gave previous suggestion and expectation that the use of electronic media should be more vary such as the use of blogs and social media instead of only relying on email activities between the lecturer and students. Therefore, more creativity is a must in teaching writing so that the students can be more motivated in producing a good English essay.

\section{REFERENCES}

Ahmadi, D., Maftoon, P., \& Mehrdad, A. G. (2012). Investigating the effects of two types of feedback on EFL students' writing. Procedia Social and Behavioral Sciences, 46, 2590 - 2595.

Amir, A., Ismail, K., \& Hussin, S. (2011). Blogs in Language Learning: Maximizing Students' Collaborative Writing. Procedia - Social and Behavioral Sciences, $18,537-543$.

Ariyanti, A. (2016a). Shaping Students' Writing Skills: The Study of Fundamental 
Aspects in Mastering Academic Writing. Indonesian Journal of EFL and Linguistics, 1(1), 63-77.

Ariyanti, A. (2016b). The Teaching of EFL Writing in Indonesia. DINAMIKA ILMU, 16(2), 263-277.

Ariyanti, A. (2017). Foreign Language Anxiety in Academic Writing. DINAMIKA ILMU, 17(1).

Chang, N., Watson, A. B., Bakerson, M. A., Williams, E. E., McGoron, F. X., \& Spitzer, and B. (2012). Electronic feedback or handwritten feedback: What do undergraduate students prefer and why? Journal of Teaching and Learning with Technology, 1(1), 1-23.

Creswell, J. W. (2012). Educational Research: Planning, Conducting, and Evaluating Quantitative and Qualitative Research (4th ed.). Lincoln: Pearson.

Creswell, J. W. (2014). Research Design: Qualitative, Quantitaive, and Mixed Methods Approaches. Thousand Oaks, California: Sage Publication, Inc.

Efrontlearning. (2014). E-Learning: Concepts, Trends, Aplication. San Francisco, California: Epignosis LLC.

Farid, S., \& Samad, A. A. (2012). Effects of Different Kind of Direct Feedback on Students' Writing. Procedia - Social and Behavioral Sciences, 66, 232-239.

Ghirardini, B. (2011). E-learning Methodologies: A Guide for Designing and Developing E-learning Courses. Caracalla, Rome: Food and Agriculture Organization of the United Nations.

Huwari, I. F., \& Al-Khasawneh, F. M. (2013). The Reasons behind the Weaknesses of Writing in English among Pre-year Students' at Taibah University. English for Specific Purposes World, 14(38).

Leavy, P. (2014). The Oxford Handbook of Qualitative Research. New York: Oxford University Press.

Linn, R. L., \& Miller, M. D. (2005). Measurement and Assessment in Teaching (9th ed.). Upper Saddle River, NJ: Pearson Prentice Hall.

Lipnevich, A. A., \& Smith, J. K. (2008). Response to Assessment Feedback: The Effects of Grades, Praise, and Source of Information. Princeton, New Jersey.

Miles, M. B., Huberman, .AM., \& Saldana, J. (2014). Qualitative Data Analysis: A Methods Sourcebooks (3rd ed.). California: SAGE Publications, Inc.

Price, M., Handley, K., Millar, J., \& O'Donovan, B. (2010). Feedback: All that effort, but what is the effect? Assessment \& Evaluation in Higher Education, $35(3), 277-289$.

Rajaram, S. (2009). Application of E-Learning in Creative Writing. Journal of Library \& Information Technology, 29(1).

Rezaei, M., \& Jafari, M. (2014). Investigating the Levels, Types, and Causes of Writing Anxiety among Iranian EFL Students: A Mixed Method Design. Procedia - Social and Behavioral Sciences, 98, 1545-1554.

Sambell, K. (2011). Rethinking Feedback in Higher Education: An Assessment for Learning Perspective. Bristol: EsCalate.

Sanu, L. O. (2016). EFL Students' Preferences toward the Lecturer's Corrective Feedback in Business Letters Writing. DINAMIKA ILMU, 16(2), 221-243. 